\title{
Role of Bak in UV-induced apoptosis in skin cancer and abrogation by HPV E6 proteins
}

\author{
Sarah Jackson, ${ }^{1}$ Catherine Harwood, ${ }^{1}$ Miranda Thomas ${ }^{2}$, Lawrence Banks, ${ }^{2}$ and Alan Storey ${ }^{1,3}$ \\ ${ }^{1}$ Imperial Cancer Research Fund, Skin Tumour Laboratory, Centre for Cutaneous Research, London E1 2AT, UK; \\ ${ }^{2}$ International Centre for Genetic Engineering and Biotechnology, Trieste 34012, Italy
}

Ultraviolet B (UVB) damage is recognized as the most important etiological factor in the development of skin cancer. Human papillomaviruses (HPV) have also been implicated in the disease, although the mechanism of action of these viruses remains unknown. We present evidence here that Bak protein is involved in signaling apoptosis in the skin in response to UVB damage, and that cutaneous HPV E6 proteins target and abrogate Bak function by promoting its proteolytic degradation both in vitro and in regenerated epithelium. Additionally, HPV positive skin cancers had undetectable levels of Bak in contrast to HPV negative cancers, which expressed Bak. This study supports a link between the virus and UVB in the induction of HPV-associated skin cancer and reveals a survival mechanism of virally infected cells.

[Key Words: HPV; skin cancer; apoptosis; UV; proteolysis]

Received June 2, 2000; revised version accepted October 18, 2000.

Apoptosis, or programmed cell death, triggers a series of events leading to the efficient elimination of a cell. In actively proliferating tissues, such as the epidermis of the skin, apoptosis-like phenomena are often found, as seen in the regression of hair follicles (Sieberg et al. 1995; Lindner et al. 1997) and in terminal differentiation (McCall and Cohen 1991; Haake and Polakowska 1993; Polakowska et al. 1994). The formation of "sunburn cells", frequently observed in epidermis treated with UVB, have the apoptotic characteristic of condensed nuclei (Young 1987; Schwarz et al. 1995), the response to UVB radiation being in part dependent upon the expression of p53 (Ziegler et al. 1994). This p53-driven response, often termed cellular proofreading, eliminates rather than repairs, severely damaged cells, however p53-independent pathways have also been described (Allday et al. 1995; Gniadecki et al. 1997).

Solar UVB radiation represents one of the major environmental impacts for humans (Miralles et al. 1998) resulting in about 40,000 new cases of nonmelanoma skin cancer (NMSC) arising annually in the UK and 1,000,000 in the USA. In particular, it is the UVB portion (280-320 $\mathrm{nm}$ ) of sunlight which stimulates the induction of somatic mutations through the formation of pyrimidine dimers and photoproducts (Herzinger et al. 1995). It has been suggested that failure to repair this DNA damage or to remove severely damaged cells by apoptosis may lead to the replication of deleterious mutations and ulti-

${ }^{3}$ Corresponding author.

E-MAIL a.storey@icrf.icnet.uk; FAX 44-207-882-7171.

Article and publication are at www.genesdev.org/cgi/doi/10.1101/gad. 182100 . mately to carcinogenesis (for review, see Griffiths et al. 1998). There may also be a role for other factors including immune response, genetic disposition, and infection by viruses such as HPV (for review, see Proby et al. 1996). Populations at most risk of developing HPV-associated NMSC are individuals with the rare inherited disease, Epidermodysplasia verruciformis (EV), and immunosuppressed patients, in particular renal transplant recipients (RTRs) who have a well-documented 50- to 100-fold increased risk of cutaneous squamous cell carcinoma (SCC). In both EV and immunocompromised patients, warts and SCCs contain a diverse spectrum of HPV types, the virus being present in $\sim 80 \%$ of lesions from immunocompromised patients and $\sim 30 \%$ of those from immunocompetent patients (Storey et al. 1998; Harwood et al. 2000, and references therein). The co-localization of warts and cancers at sun-exposed sites suggests a possible interaction between HPV and UVB irradiation (for review, see Proby et al. 1996).

The pro-apoptotic effector Bak is expressed in human epidermal keratinocytes (Mitra et al. 1997; Tomkova et al. 1997) and is a target of the E6 protein of anogenital HPVs (Thomas and Banks 1998). Here we demonstrate that the impact of cutaneous HPV E6 proteins resulting in Bak dysfunction has important physiological implications with regard to skin cancer development.

\section{Results}

Accumulation of Bak following UVB irradiation is abrogated by HPV E6 proteins

To investigate whether UVB damage might be a physiologically relevant inducer of Bak in the skin, primary 
normal human keratinocytes (the natural target of cutaneous HPVs), HT1080 cells which express wild-type p53 and human p53-null keratinocytes (RTS3b, Rapp et al. 1997) were treated with UVB and harvested at 0, 8, 16, 24,36 , and $43 \mathrm{~h}$ postirradiation. Equal amounts of protein extract were fractionated by SDS-PAGE and analyzed by Western blotting using antibodies specific for Bak and p53. The results demonstrate that UVB was a potent inducer of Bak in each cell line tested, including RTS3b cells, indicating that this induction can occur independently of p53 (Fig. 1A).

We then asked whether the E6 proteins from a spectrum of HPV types could abrogate the increase in Bak protein levels following UVB treatment. We chose to investigate E6 proteins derived from diverse HPV groups, including HPV 5 (found in cutaneous carcinomas in EV), HPV 10 (found in benign warts and SCCs of RTRs), and HPV 77 (a novel type identified in SCCs and warts from RTRs), and compared their activity with that of the anogenital type HPV 18. UVB irradiation of HT1080 cell lines expressing the different E6 proteins (Jackson and Storey 2000) increased Bak protein levels in the HT1080 vector control cells as before but not in cells expressing the E6 proteins (Fig. 1B). In the HPV18 E6 cells, p53 protein failed to accumulate following UVB exposure as its degradation is efficiently promoted by anogenital HPV types (Scheffner et al. 1990; Werness et al. 1990), thereby blocking the induction of $\mathrm{p} 21$. In contrast, the

A

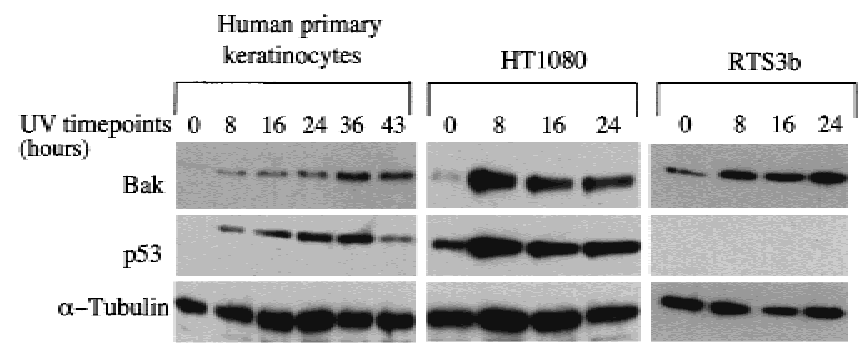

B

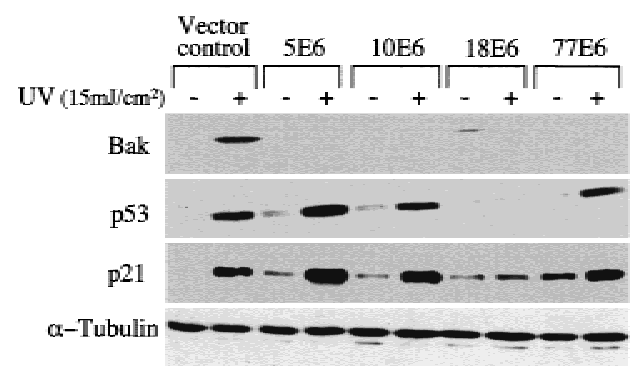

$\mathrm{C}$

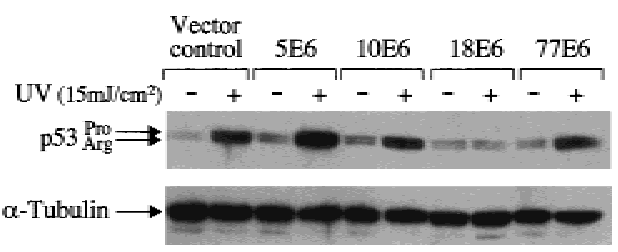

HPV 5, 10, and 77 E6-expressing cells, in which the cutaneous E6 proteins are unable to degrade p53, have increased levels of both $\mathrm{p} 53$ and $\mathrm{p} 21$ protein following UVB damage. This suggests that the activity of the cutaneous E6 proteins, unlike those of other mucosal HPVs, is specifically directed toward Bak rather than p53. Furthermore, analysis of two other pro-apoptotic members of the Bcl-2 family, Bax and Bik, were not induced by UVB and were not targeted for degradation by E6 (S. Jackson and A. Storey, unpubl.). A common polymorphism at codon 72 of p53 results in either an arginine or proline at that position, the arginine being more susceptible to proteolytic degradation promoted by anogenital HPV E6 proteins (Storey et al. 1998). Because HT1080 cells express both p53 isoforms, which are easily identified by their different mobilities on gels, we tested whether the cutaneous E6 proteins were also able to preferentially target the arginine form. Resolution of the p53 isoforms on a lower percentage polyacrylamide gel showed that neither was targeted for degradation by the cutaneous HPV E6 proteins (Fig. 1C).

Analysis of Bak mRNA by Northern blotting showed that it was expressed at low levels in all the cell types used above and did not increase following treatment with UVB (data not shown) implying that the increase in Bak protein detected above was due to stabilization of the protein. To confirm this, the half-life of Bak was examined in UVB-irradiated HT1080 cells (Fig. 1D).

D

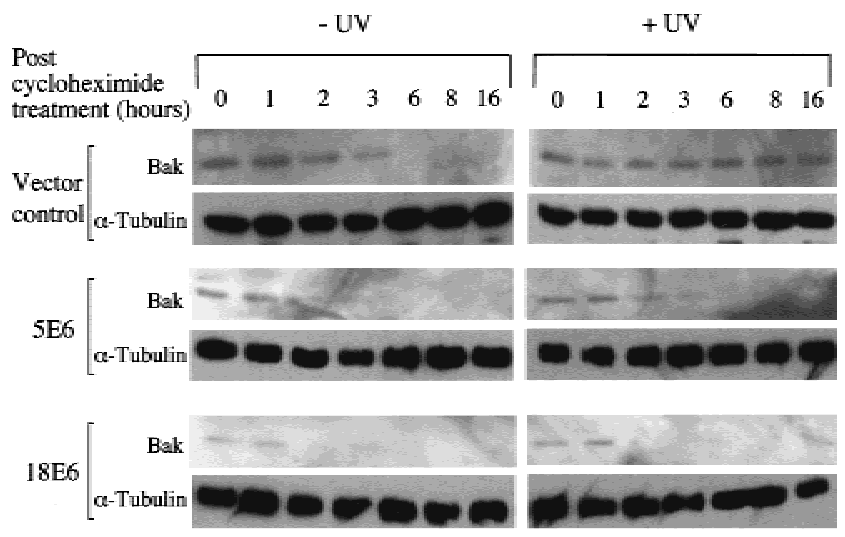

Figure 1. Induction of Bak by UVB and abrogation of the Bak pathway by E6 proteins. (A) Human primary keratinocytes, HT1080 cells and human p53-null keratinocytes (RTS3b line) were treated with UVB $\left(15 \mathrm{~mJ} / \mathrm{cm}^{2}\right)$ and the cells harvested at 0-43 h (only human primary keratinocytes survived after $24 \mathrm{~h}$ ). Equal protein samples were resolved by SDS-PAGE, with Bak, p53 and $\alpha$-tubulin levels detected by Western blotting using monoclonal antibodies. (B) HT1080 E6 polyclonal cell lines were treated with UVB $\left(15 \mathrm{~mJ} / \mathrm{cm}^{2}\right)$ and the cells harvested $24 \mathrm{~h}$ later. Proteins were detected as in $A$. The membrane was exposed to X-ray film for 1 min prior to development. $(C)$ Polymorphic forms of $\mathrm{p} 53$ from $B$ were resolved on a 10\% PAG and detected as previously. (D) HT1080 E6 cells were treated with 60 $\mu \mathrm{g} / \mathrm{mL}$ cycloheximide $5 \mathrm{~min}$ post $\mathrm{UV}$ treatment $\left(15 \mathrm{~mJ} / \mathrm{cm}^{2}\right)$. Protein extracts were prepared at the indicated time points following cycloheximide treatment and Bak levels determined by Western blotting. The membrane was exposed to X-ray film for 20 min prior to development to detect low levels of Bak. 
Analysis of Bak from UVB-irradiated cells incubated with cycloheximide showed that the Bak half-life was significantly extended. In agreement with our previous observations, this increase in Bak half-life was not seen in cells expressing either the HPV5 or HPV18 E6 protein. In HPV5 E6-expressing cells the Bak half-life following UVB treatment was reduced to the level seen in the untreated vector control cells, whereas it was reduced even further by HPV18 E6 either with or without UVB irradiation.

\section{E6 promotes proteolytic degradation of Bak}

To investigate whether HPV5 E6 and HPV18 E6 promoted proteolytic degradation of Bak, cell lines were incubated with lactacystin, a specific inhibitor of proteasome activity (Fenteany et al. 1994, 1995; Dick et al. 1996; Craiu et al. 1997). The results in Figure 2A demonstrate that, although Bak protein levels increased in the vector control cells following UVB damage, no increase was seen in the HPV5 and HPV18 E6 cells treated with UVB alone. Only when lactacystin was added to UVB-treated E6-expressing cells prior to harvesting was Bak then detected at levels comparable to the control cells, suggesting that, at least in these cells, additional DNA damage was required to initiate Bak accumulation. This restoration of Bak levels in the E6 expressing cells was also accompanied by an increase in the number of apoptotic cells as determined by TUNEL staining (Fig. 2B). Further analysis of proteins extracted from lactacys- tin-treated UVB-irradiated cells in the presence of iodoacetimide revealed the presence of many higher molecular weight, modified Bak species (Fig. 2C).

\section{Bak is induced in normal skin by UVB radiation}

We extended our observations in monolayer cell cultures to normal skin specimens treated with UVB. Skin was obtained from an abdominal biopsy and subsequently maintained in organ culture, UVB-irradiated (45 and 225 $\mathrm{mJ} / \mathrm{cm}^{2}$ ) and processed for immunohistochemistry. We observed strong p21 staining throughout the epidermis in accordance with its role in terminal differentiation (Ponten et al. 1995; Missero et al. 1996). The induction of both p53 and Bak proteins following UVB damage was not restricted to a particular stage of keratinocyte differentiation but instead occurred throughout the epidermal layers in the skin, including the basal cell compartment where putative stem cells reside (Fig. 3). Spontaneously apoptosing cells in non-UVB-treated skin were rarely detected; however, upon UVB exposure, apoptotic cells were readily detected throughout the epidermis using TUNEL staining, with the staining concentrated in a rim of condensed chromatin.

\section{HPVs inhibit Bak accumulation and apoptosis in regenerated human skin}

The finding that UV up-regulated Bak expression in skin, coupled with the promotion of Bak proteolysis by E6
A

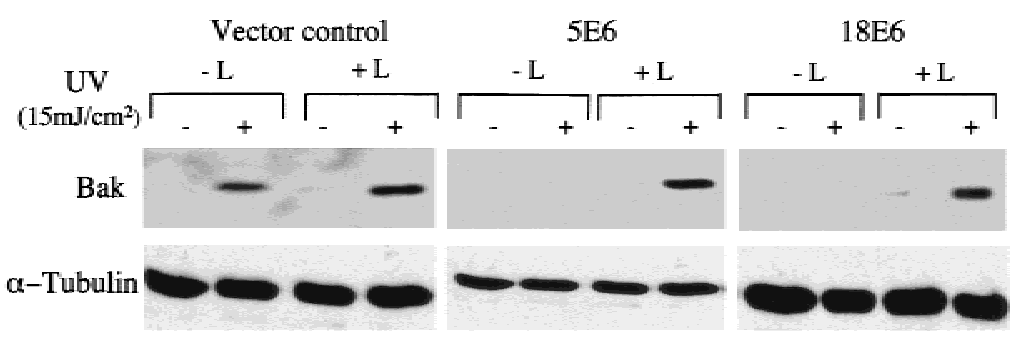

B

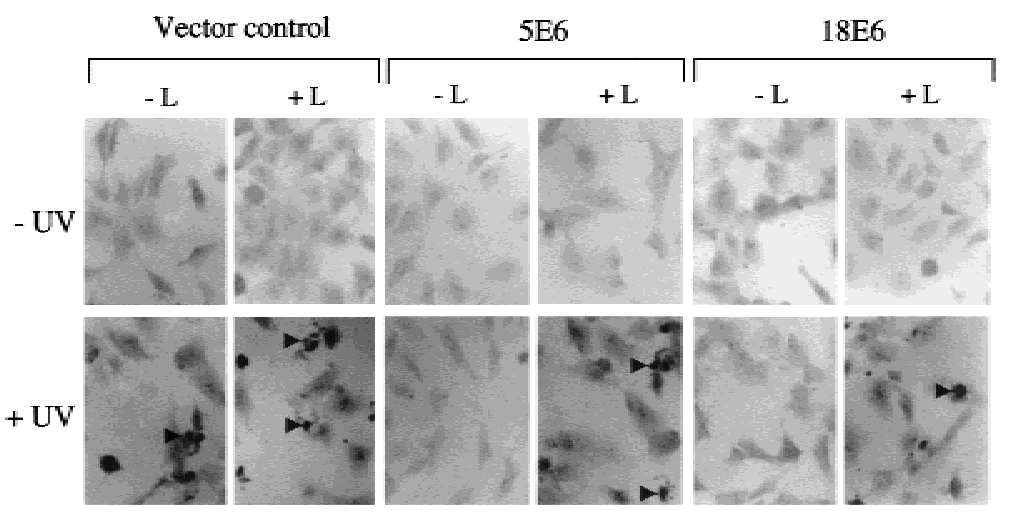

C

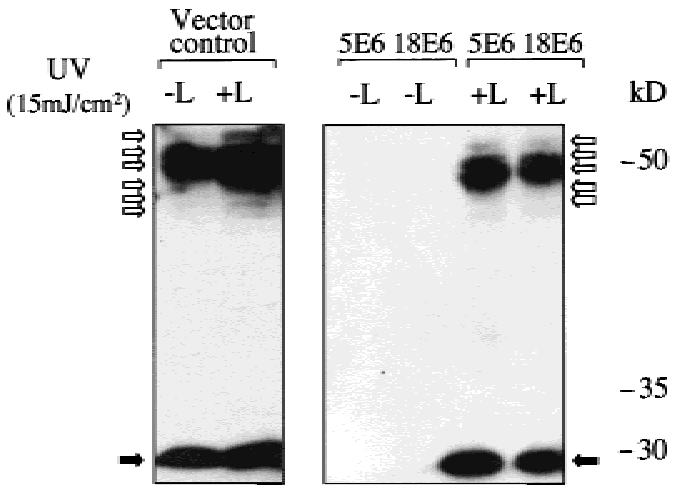

Figure 2. Ubiquitin-dependent proteolytic degradation of Bak and induction of apoptosis following UV treatment. (A) Western blot analysis of endogenous Bak levels in HT1080 vector control cells, 5E6 cells and $18 \mathrm{E} 6$ cells grown in the presence $(+\mathrm{L})$ and absence $(-\mathrm{L})$ of the proteasome inhibitor lactacystin $(5 \mu \mathrm{M})$ with $(+)$ and without $(-)$ UVB $\left(15 \mathrm{~mJ} / \mathrm{cm}^{2}\right)$ treatment. Lactacystin was added $2 \mathrm{~h}$ prior to the 24 -h cell harvesting timepoint. (B) Parallel cultures of cells seeded onto glass coverslips were treated with UV and lactacystin as in $A$. Cells were fixed in paraformaldehyde and apoptotic cells detected by TUNEL (Magnification, 200×). (C) HT1080 cells were exposed to UVB $\left(15 \mathrm{~mJ} / \mathrm{cm}^{2}\right)$ and were grown in the presence $(+\mathrm{L})$ and absence $(-\mathrm{L})$ of lactacystin for $2 \mathrm{~h}$ prior to cell harvesting, as in A. Cells were lysed $24 \mathrm{~h}$ post UVB in SDS sample buffer diluted in RIPA buffer containing iodoacetamide $(10 \mathrm{mM})$, ubiquitinated Bak was detected by Western blotting. 


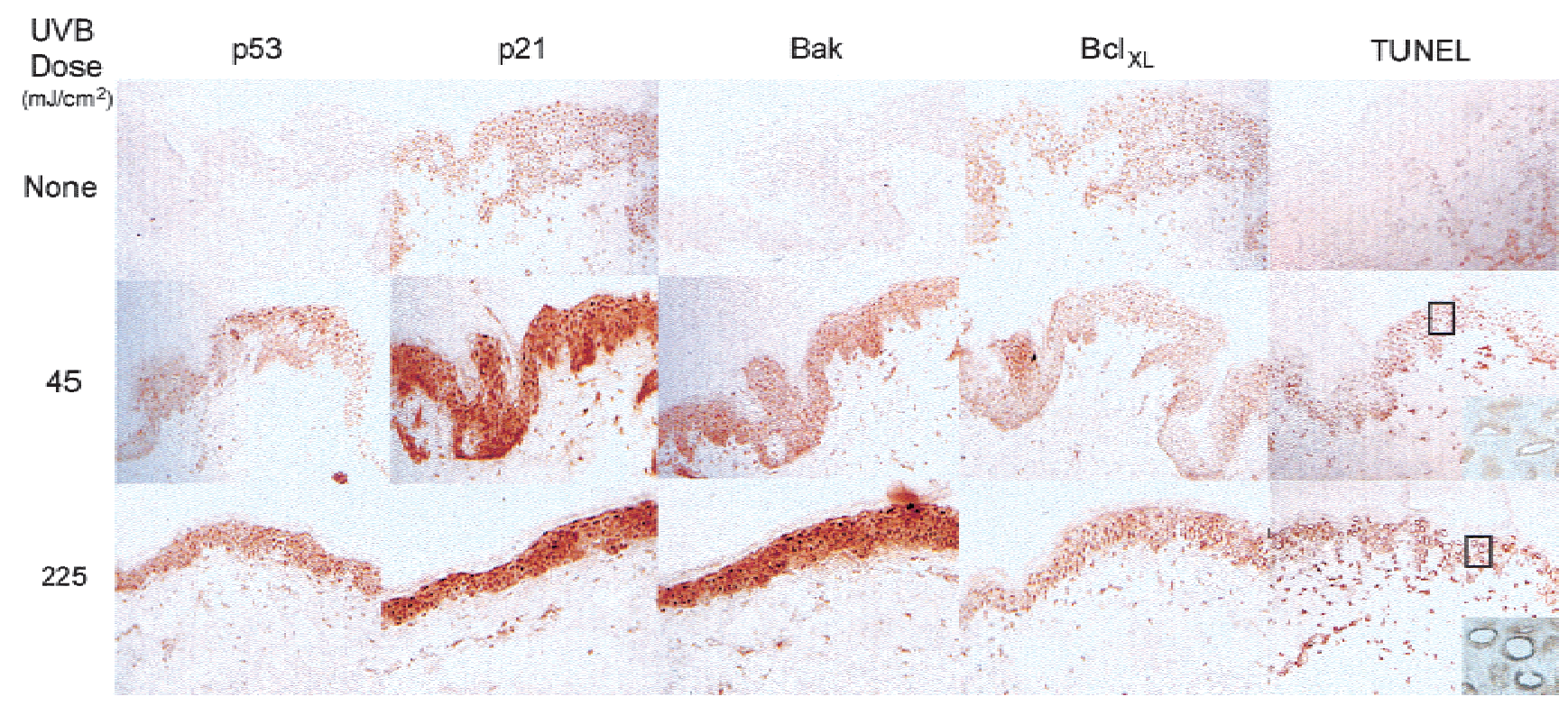

Figure 3. Bak induction in normal skin by UVB. Skin specimens were irradiated with 45 or $225 \mathrm{~mJ} / \mathrm{cm}^{2} \mathrm{UVB}$ and snap frozen $24 \mathrm{~h}$ posttreatment for immunohistochemical analysis. Apoptotic cells were detected using TUNEL (original magnification, 100×, insert, $400 \times)$.

proteins following UV treatment, suggests that E6 expression is likely to have significant effects in modulating the cellular responses of skin exposed to UV. To explore this further, we used a more physiologically appropriate organotypic cell culture system, which permits the regeneration of stratified differentiated epithelium in vitro and can be used to mimic viral infection. Primary human keratinocytes were transfected with the E6 and E7 genes of either HPV77, or for comparative purposes, HPV18. For cultures where HPV genes were transfected, the E7 gene, in addition to E6, is required to obtain optimal epithelial regeneration. Reconstituted epidermal sheets were then irradiated with UV doses, which caused apoptosis in the explanted skin and were processed $24 \mathrm{~h}$ later. As expected, control cells not transfected with HPV genes showed strong induction of both p53 and Bak in all cell layers following UV treatment, with many apoptotic cells being detected throughout the epidermis as assessed by TUNEL staining (Fig. 4). In contrast, keratinocytes transfected with HPV E6 and E7 genes of either HPV77 or HPV18 showed no increase in Bak levels following irradiation. In agreement with our findings in monolayer cultures, p53 levels increased in both control and HPV77 transfected cells but not in cells transfected with HPV18 genes. Nevertheless, apoptotic cells were not detected in any cell layers of the epithelia regenerated from keratinocytes transfected with either HPV77 or HPV18, despite the increased p53 levels in the HPV77 transfected cells (Fig. 4). To gain further insights into the mechanism and causal effects of Bak degradation by E6 in our regenerated skin model, we used HA-tagged Bak mutants that were either unable to be proteolytically degraded $(\Delta \mathrm{C})$ or signal apoptosis $(\Delta \mathrm{GD})$ (Chittenden et al. 1995), to investigate whether Bak degradation was required to regenerate an epithelium in vitro. Transfec- tion of primary keratinocytes with plasmids expressing either $\Delta \mathrm{C}$ or Bak resulted in apoptotic death. In contrast to the wild-type protein, the activity of the $\Delta \mathrm{C}$ mutant was not inhibited by cotransfection with either HPV18 or HPV77 E6 (Fig. 5A). Only the $\Delta$ GD- or $\Delta$ GD/E6-transfected cells survived transfection and these were then seeded onto dermis. Both formed a differentiated epithelium with evidence of cornification that was histologically comparable to normal primary keratinocytes. The tagged protein is readily detectable in the $\Delta$ GD-transfected cells using an anti-HA monoclonal antibody, with no increase in expression following UV irradiation (Fig. $5 \mathrm{~B})$. By comparison, the $\Delta \mathrm{GD}$ protein was not detected in the E6 transfected cells even following UV treatment.

\section{Bak expression in nonmelanoma skin cancers}

The elimination of Bak in the epidermis by different E6 proteins invokes a mechanism by which these diverse viral types could play a role in skin cancer development. To test this idea we initiated a pilot study to investigate whether HPV-positive skin lesions had detectable levels of Bak protein. After HPV typing, SCC biopsies that were either HPV-positive or -negative were selected for analysis. Immunohistochemistry showed that the Bak protein was not present in HPV-positive lesions but in contrast was detected to varying degrees in all five HPV-negative biopsies tested (Table 1). The p53 positive staining in the HPV-negative tumor suggests that this may be reflective of p53 gene mutations as these are frequently found in cutaneous lesions (Ziegler et al. 1994; Jonason et al. 1996; Ren et al. 1996). In contrast, p21 protein levels are high in all the biopsies processed, even in the absence of detectable p53. Interestingly, protein levels of $\mathrm{Bcl}-\mathrm{x}_{\mathrm{L}}$, the anti-apoptotic partner of Bak, were negligible in all of the 


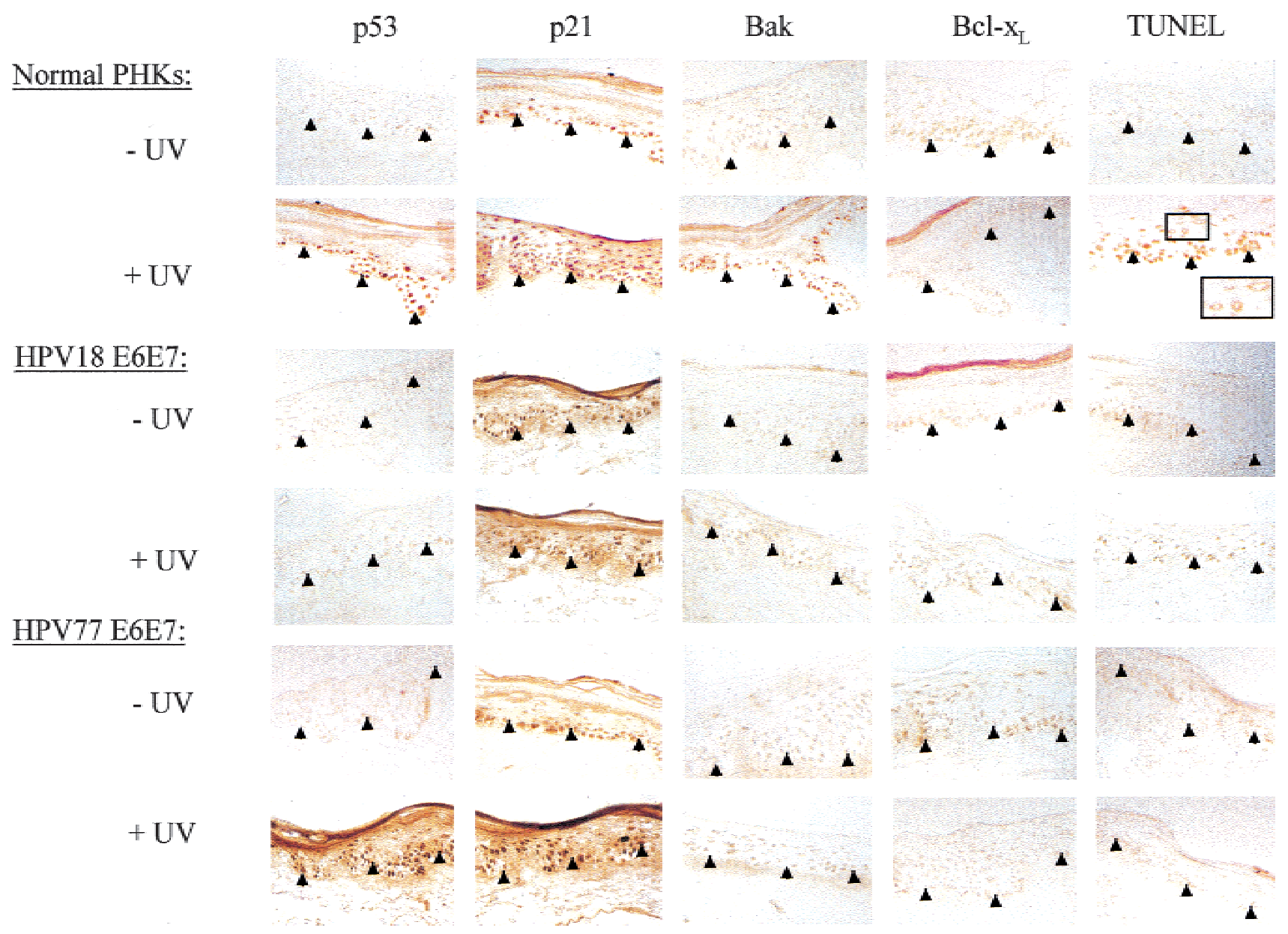

Figure 4. Effects of irradiation on HPV18 and 77 E6/E7 transfected keratinocytes grown in organotypic culture. Endogenous p53, p21, Bak and Bcl-xL protein levels were detected by immunohistochemistry in HPV 18 and 77 E6/E7 cultures $24 \mathrm{~h}$ post UV treatment (45 $\mathrm{mJcm}^{-2}$ ) and compared to control PHK raft cultures (original magnification, 100×).

biopsies tested. In summary, Bak protein was detected in 5/5 HPV-negative SCC lesions, whereas in marked contrast 5/5 HPV-positive SCC biopsies had negligible levels of Bak protein $(P=0.004)$. These results suggest that the HPV-containing tumors may have a higher proliferative potential. Staining for the proliferation marker Ki67 in conjunction with TUNEL staining showed that, although both the HPV-positive and -negative tumors showed similar levels of Ki67 expression, the HPV-negative tumors contained many more apoptotic cells compared to the HPV-positive tumors.

\section{Discussion}

Our previous studies have shown that both p53-dependent and p53-independent apoptotic pathways are inhibited by cutaneous E6 proteins (Jackson and Storey 2000). Such an overall effect may influence lesion development by altering the balance between proliferation and apoptosis, a key factor in determining the net growth of a tumor (Arends et al. 1994). We demonstrated that both normal human keratinocytes and HT1080 cells treated with UVB had dramatically increased levels of the Bak protein brought about by an increase in half-life, pointing to a role for Bak in promoting apoptosis in UVBdamaged skin. In contrast, HT1080 cell lines expressing the anogenital and cutaneous HPV E6 proteins showed no such increase in Bak levels following UVB damage. Bak is the first identified target of cutaneous E6 proteins. The mechanism of degradation, shared with anogenital HPVs, indicates that the cutaneous E6 proteins are able to discriminate between p53 and Bak as targets. This is critical to HPV77 since it utilizes transcriptionally active p53 to increase viral gene transcription (Purdie et al. 1999|. Analysis of clonal p53 mutant cell patches in human skin demonstrated that they had little or no precancerous potential (Jonason et al. 1996; Ren et al. 1996). Our results suggest that the elimination of Bak protein by E6 leads to a decrease in apoptosis in UV-irradiated cells, which could in turn promote tumor formation. This posed the question as to what was the mechanism for the abrogation of Bak by the E6 proteins following UVB damage. We conclude from experiments using the 


\section{Jackson et al.}

A

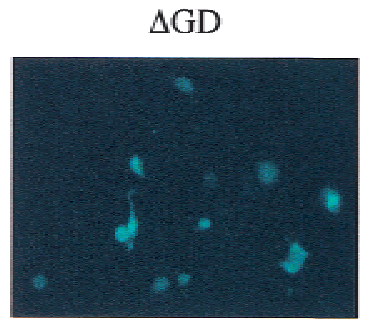

$\Delta \mathrm{C}$

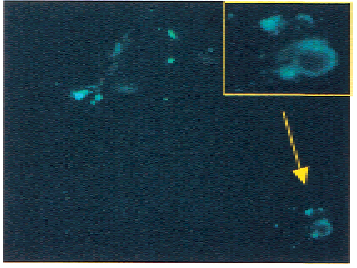

Bak

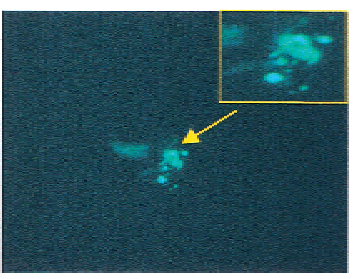

B
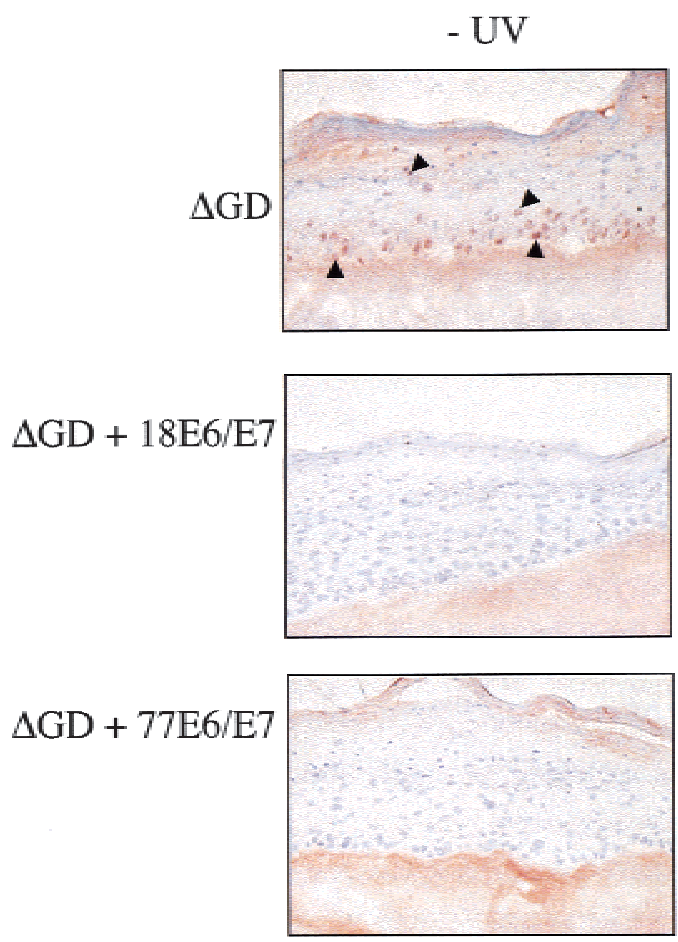

$\Delta \mathrm{GD}+18 \mathrm{E} 6 / \mathrm{E} 7$

$\Delta \mathrm{C}+18 \mathrm{E} 6 / \mathrm{E} 7$

Bak +18E6/E7
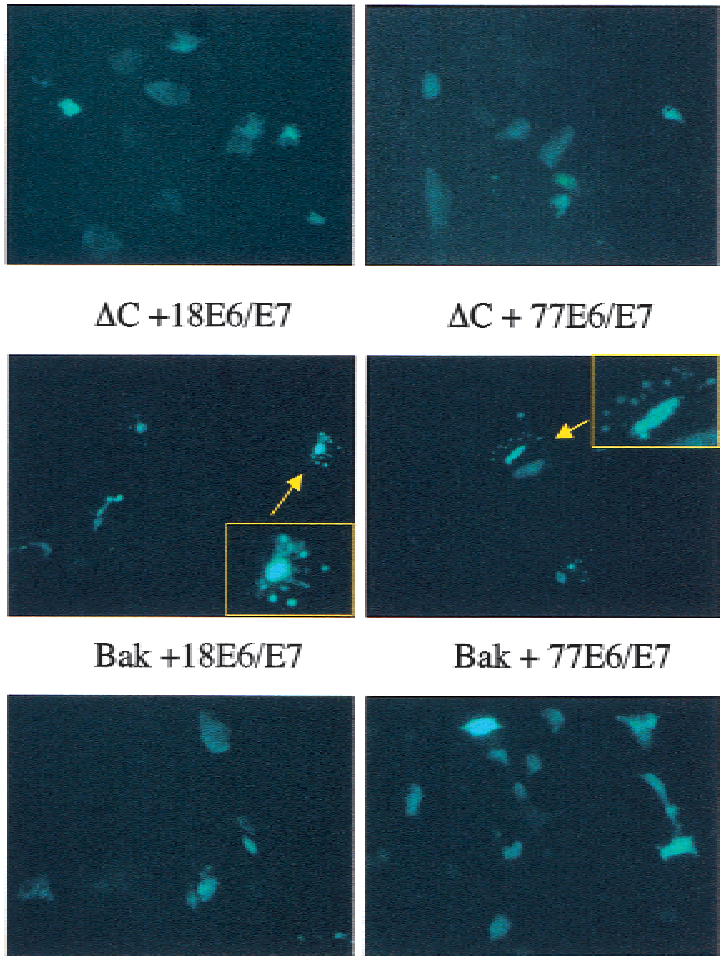

$\mathrm{Bak}+77 \mathrm{E} 6 / \mathrm{E} 7$

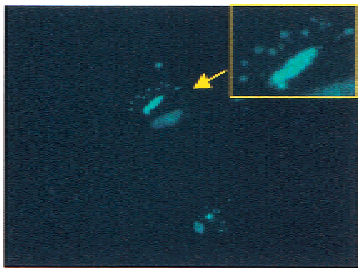

$+\mathrm{UV}$
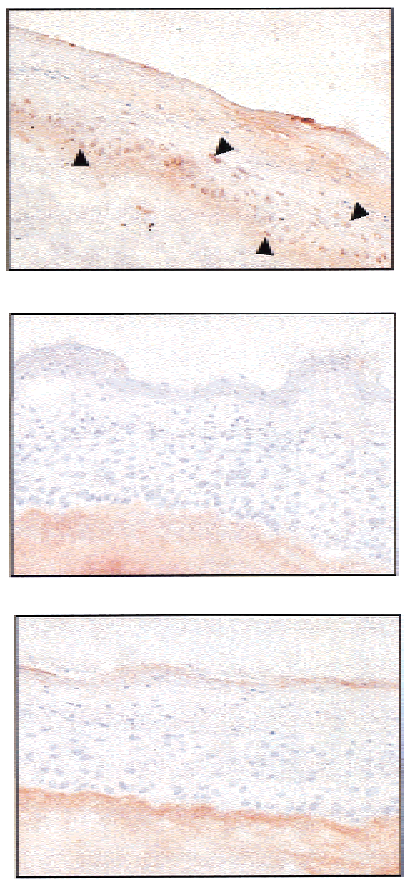

Figure 5. Inhibition of Bak apoptotic activity but not degradation is required to regenerate epidermis in vitro. $(A)$ Normal keratinocytes were transfected with either Bak or the $\Delta \mathrm{GD}$ or $\Delta \mathrm{C}$ mutants either alone or together with HPVE6/E7. EGFP was used as a marker of transfection. $16 \mathrm{~h}$ post-transfection the cells were monitored for morphological signs of apoptosis (membrane blebbing, nuclear condensation and fragmentation) (Magnification, 200x; inserts, 400×). (B) $\Delta$ GD and $\Delta$ GD/E6/E7 cells were seeded onto de-epidermalized dermis and allowed to reform an epithelium. The cells were irradiated with $45 \mathrm{mJcm} \mathrm{cm}^{-2} \mathrm{UVB}$, harvested $8 \mathrm{~h}$ posttreatment and processed for immunohistochemistry. Sections were counterstained with haematoxylin. Positively stained cells are indicated by arrowheads. (Magnification, 200×) 
Table 1. TUNEL and endogenous p53, p21, Bak, Bcl- $x_{L}$, Ki67 levels detected by immunostaining in HPV positive/negative skin lesions

\begin{tabular}{|c|c|c|c|c|c|c|c|c|}
\hline Biopsy code & Lesion & HPV type(s) & p53 & $\mathrm{p} 21$ & Bak & $\mathrm{Bcl}-\mathrm{x}_{\mathrm{L}}$ & Ki67 & TUNEL \\
\hline \multicolumn{9}{|c|}{ HPV positive lesions } \\
\hline $7 \mathrm{~F}$ & SCC & 37 & - & +++ & - & - & +++ & + \\
\hline $7 \mathrm{~L}$ & SCC & 10,23 & ++ & - & - & - & + & $+/-$ \\
\hline 7J & Bowen's/Dysplastic & $\mathrm{RTR} \times 32$ & ++ & - & - & - & ++ & + \\
\hline 7B & Keratosis & 77 , vs 92-1, 14 & - & - & - & - & + & - \\
\hline $9 \mathrm{~A}$ & SCC & pso $\times 1$ & $+/-($ focal $)$ & +++ & - & - & ++ & + \\
\hline \multicolumn{9}{|c|}{ HPV negative lesions } \\
\hline $9 \mathrm{E}$ & SCC & - & $+($ focal $)$ & - & $+/-$ & - & ++ & ++ \\
\hline $9 \mathrm{~K}$ & SCC & - & - & + & ++ & - & - & ++ \\
\hline $9 \mathrm{H}$ & SCC & - & - & ++ & ++ & - & + & +++ \\
\hline $7 \mathrm{H}$ & SCC/Bowen's & - & $+/-$ & ++ & $+/-$ & - & ++ & +++ \\
\hline $7 \mathrm{~V}$ & SCC & - & +++ & +++ & +++ & - & ++ & ++ \\
\hline
\end{tabular}

SCC, Squamous cell carcinoma. Fisher's exact test of Bak staining between HPV positive and negative lesions: $P=0.004$.

proteasome inhibitor lactacystin, that the E6 proteins promoted proteolytic degradation of Bak.

To place the UVB induction of Bak in a physiologically meaningful context, we investigated Bak induction in UVB-treated skin, as Bak does not appear to be induced by $\gamma$-radiation (Burger et al. 1998). UVB induced Bak and p53 throughout the epidermal layer. These findings, together with our cellular experiments, suggested that HPV E6 proteins may have the potential to inhibit Bakinduced apoptosis in skin following UVB damage, resulting in the accumulation of deleterious mutational changes, which further increase the genetic instability of HPV-containing lesions. To test this hypothesis, we expressed E6 and E7 genes in an organotypic model of skin. Irradiation of epidermis regenerated from HPV-transfected keratinocytes showed that the cells failed to accumulate Bak and did not undergo apoptosis. This underscores the importance of the elimination of cells damaged by UV and how such cells can persist in HPV infected lesional tissue. Our results demonstrate that the apoptotic function of Bak must be tightly regulated in tissue development. Although low levels of Bak are required to regenerate the epidermis in vitro, the fact that the $\Delta$ GD mutant, which cannot signal apoptosis, does not interfere with keratinocyte terminal differentiation indicates that Bak degradation per se is not required to obtain regenerated skin.

The perturbation of apoptotic responses by HPVs has important clinical implications for NMSC development. Immunostaining of biopsies demonstrated that the majority of HPV-negative SCCs were positive for the Bak staining. In contrast, all the HPV-positive SCCs had negligible levels of the Bak protein. Although this initial pilot study is small and would need to be extended, it nevertheless indicates that the detection of Bak in the HPV-negative tumors may reflect that some measure of response to endogenous growth control still exists to promote active cell death in these cancers. This is in agreement with reports where the detection of Bak protein positively correlates with the onset of apoptosis in human colon carcinomas (Partik et al. 1998). The failure to detect endogenous Bak protein in the HPV-positive tumors, together with a marked decrease in the number of apoptotic cells compared to the HPV negative tumors and the continued expression of proliferation markers, suggests that the balance between apoptosis and proliferation is altered in HPV-containing lesions. The fact that HPV-associated NMSC occurs predominantly at sun-exposed body sites indicates that it is the abrogation by E6 of UV-induced, rather than spontaneous apoptosis that is important in tumor formation and progression of HPV-containing lesions.

In summary, we have shown that Bak functions in a pathway that removes precancerous cells from the epidermis resulting from UVB damage. Evidence that HPVpositive NMSC lesions have undetectable levels of Bak protein, together with results suggesting that anogenital and cutaneous HPVs may possess the ability to use a common antiapoptotic mechanism, raise the exciting possibility that the abrogation of Bak by the HPV E6 proteins is a common means of promoting the survival of virally infected cells. This may provide a useful target for intervention against skin lesions harboring a wide variety of HPV types.

\section{Materials and methods}

\section{Cells and transfections}

HT1080 polyclonal cell lines expressing HPV 5, 10, 18, and 77 E6 were made as described previously (Jackson and Storey 2000). Plasmids encoding HA-tagged Bak, the $\Delta \mathrm{GD}$ and $\Delta \mathrm{C}$ mutants $(0.5 \mu \mathrm{g})$ (Chittenden et al. 1995) and the E6 and E7 genes (3 $\mu \mathrm{g})$ of the different HPV types were transfected into primary cultures of human epidermal keratinocytes using TransFast (Promega). Human primary keratinocytes and p53-null keratinocytes (RTS3b, Rapp et al. 1997) were grown in DMEM/Ham's F12 $(3: 1)$ supplemented with $10 \%$ FCS and growth factors. Tissue specimens used for immunohistochemistry were frozen in Cryobed mountant and stored at $-70^{\circ} \mathrm{C}$. Keratinocytes were transfected using Transfast (Promega) with an efficiency of $\sim 90 \%$ as judged by the fluorescence resulting from cotransfection of an EGFP plasmid. Organotypic cultures were essentially prepared on de-epidermalized dermis as described by Prunerias et al. (1983). Briefly, the reticular dermal surface was repopulated with human fibroblasts and keratinocytes were seeded on 
the papillary dermal surface and allowed to form a confluent monolayer. The culture was then raised to the air-liquid interface for a further $14 \mathrm{~d}$ before harvesting. Where required, cells were irradiated with UVB using a UVP CL-1000 ultraviolet cross-linker with F8T5 bulbs giving a spectral peak at $312 \mathrm{~nm}$.

\section{Antibodies}

The monoclonal antibodies used were Bak (Ab-2, Calbiochem), p53 (D01, ICRF), p21 (Santa Cruz), Ki67 (Dako), $\alpha$-Tubulin (Calbiochem), and anti-HA (12CA5, ICRF). The Bcl-x rabbit polyclonal antibody was obtained from Calbiochem.

\section{Western blot analysis}

Cells were incubated with lysis buffer (50 mM HEPES at pH 7.4, $250 \mathrm{mM} \mathrm{NaCl}, 0.1 \%$ Nonidet-P40 and $1 \times$ cocktail protease inhibitors [Boehringer Mannheim]) at $4^{\circ} \mathrm{C}$ for 20 min prior to harvesting. The supernatants were resolved by SDS-PAGE and transferred onto PVDF membrane according to standard procedures. The membrane was probed with specific antibodies and developed using the Amersham ECL +Plus kit according to the manufacturers instructions.

For Western blot analysis of ubiquitinated Bak, the cells were lysed in SDS sample buffer diluted in RIPA buffer $(1: 3)$ containing iodoacetamide $(10 \mathrm{mM})$ as described previously (Rodriguez et al. 1999).

\section{Half-life measurements}

HT1080 E6 cells were UV irradiated $\left(15 \mathrm{~mJ} / \mathrm{cm}^{2}\right) 5 \mathrm{~min}$ prior to the addition of $60 \mu \mathrm{g} / \mathrm{mL}$ cycloheximide and the cells incubated for the indicated time periods. Protein extracts were prepared in lysis buffer and Bak levels determined by Western blotting.

\section{Immunohistochemistry}

Biopsies were cut into $5 \mu \mathrm{m}$ sections, placed onto APES (3aminopropyltriethoxy-silane/acetone) coated slides and fixed in methanol/acetone $(1: 1)$ for $10 \mathrm{~min}$ at room temperature. Endogenous peroxidase was removed by treatment with $1 \%$ hydrogen peroxide/PBS for $20 \mathrm{~min}$ at room temperature. The sections were incubated overnight with primary antibody at $4^{\circ} \mathrm{C}$ and the secondary and tertiary antibodies were supplied in the ABC PK-6200 Universal kit (Vector Laboratories) and were used in accordance with the manufacturer's instructions. The slides were developed in DAB $16 \mathrm{mg}$ of DAB-tetrahydrochloride, $10 \mu \mathrm{L}$ of $30 \%$ hydrogen peroxide, $100 \mu \mathrm{L}$ of $0.1 \mathrm{M}$ nickel chloride, 10 $\mathrm{mL}$ PBS). TUNEL staining of tissue sections was carried out according to manufacturer's instructions (Promega, DeadEnd colorimetric apoptosis detection system), using $5 \mu \mathrm{g} / \mathrm{mL}$ Proteinase $\mathrm{K}$ incubation for $5 \mathrm{~min}$. HPV typing of biopsies was performed as described previously (Storey et al. 1998).

\section{Acknowledgments}

We thank R. Cerio and A.G. Quinn for advice on pathology of the tissue biopsies, E. Rugg for critical reading of this manuscript, and R. Hay for helpful advice. We are grateful to T. Chittenden for the gift of the plasmids encoding Bak and Bak mutants. This work was supported in part by a studentship to S.J. from the Biotechnology and Biological Sciences Research Council (BBSRC) and Roche Products Ltd., Welwyn Garden City, U.K. L.B. acknowledges the support of the Associazione Italiana per la Ricerca sul Cancro.
The publication costs of this article were defrayed in part by payment of page charges. This article must therefore be hereby marked "advertisement" in accordance with 18 USC section 1734 solely to indicate this fact.

\section{References}

Allday, M., Inman, G., Crawford, D., and Farrell, P. 1995. DNA damage in human $\mathrm{B}$ cells can induce apoptosis, proceeding from $\mathrm{G} 1 / \mathrm{S}$ when $\mathrm{p} 53$ is transactivation competent and G2/M when it is transactivation defective. EMBO J. 14: 4994-5005.

Arends, M., McGregor, A., and Wyllie, A. 1994. Apoptosis is inversely related to necrosis and determines net growth in tumours bearing constitutively expressed myc, ras, and HPV oncogenes. Am. J. Path. 144: 1045-1057.

Burger, H., Hooter, K., Boersma, A.W.M., Kortland, C.J., Van Den Berg, A.P., and Stoter, G. 1998. Expression of p53, p21Waf/Cip, Bcl-2, Bax, Bcl-X and Bak in radiation-induced apoptosis in testicular germ cell tumour lines. Int. J. Radiation Oncology Biol. Phys. 41: 415-424.

Chittenden, T., Flemington, C., Houghton, A.B., Ebb, R.G., Gallo, G.J., Elangovan, D., Chinnadurai, G., and Lutz, R.J. 1995. A conserved domain in Bak, distinct from BH1 and $\mathrm{BH} 2$, mediates cell death and protein binding functions. EMBO T. 14: 5589-5596.

Craiu, A., Gaczynska, M., Akopian, T., Gramm, C.F., Fenteany, G., Goldberg, A.L., and Rock, K.L. (1997). Lactacystin and clasto-lactacystin $\beta$-lactone modify multiple proteosome $\beta$-subunits and inhibit intracellular protein degradation and major histocompatibility complex class I antigen presentation. J. Biol. Chem. 272: 13437-13445.

Dick, L.R., Cruikshank, A.A., Grenier, L., Melandri, F.D., Nunes, S.L., and Stein, R.L. 1996. Mechanistic studies on the inactivation of the proteosome by lactacystin. J. Biol. Chem. 271: 7273-7276.

Fenteany, G., Standaert, R.F., Riechard, G.A., Corey, E.J. and Schreiber, S.L. 1994. A $\beta$-lactone related to lactacystin induces neurite outgrowth in neuroblastoma cell line and inhibits cell cycle progression in an osteosarcoma cell line. Proc. Nat1. Acad. Sci. 91: 3358-3362.

Fenteany, G., Standaert, R.F., Lane, W.S., Choi, S., Corey, E.J. and Schreiber, S.L. 1995. Inhibition of proteosome activities and subunit-specific amino terminal threonine modification by lactacystin. Science 268: 726-731.

Gniadecki, R., Hansen, M. and Wulf, H.C. 1997. Two pathways for the induction of apoptosis by ultraviolet radiation in cultured human keratinocytes. Soc. Invest. Dermatol. 109 163169.

Griffiths, H., Mistry, P., Herbert, K. and Lunec, J. 1998. Molecular and cellular effects of ultraviolet light-induced genotoxicity. Crit. Rev. Clin. Lab. Sci. 35: 189-237.

Haake, A. and Polakowska, R. 1993. Cell death by apoptosis in epidermal biology. J. Invest. Dermatol. 101: 107-112.

Harwood, C.A., Surentheran, T., McGregor, J.M., Spink, P.J., Leigh, I.M., Breuer, J., and Proby, C.M. 2000. Human papillomavirus infection and non-melanoma skin cancer in immunosuppressed and immunocompetent individuals. $I$. Med. Virol. 61: 289-297.

Herzinger, T., Funk, J.O., Hillmer, K., Eick, D., Wolf, D.A., and Kind, P. 1995. Ultraviolet B irradiation-induced G2 cell cycle arrest in human keratinocytes by inhibitory phosphorylation of the cdc cell cycle kinase. Oncogene 11: 2151-2156.

Jackson, S. and Storey, A. 2000. E6 proteins from diverse cutaneous HPV types inhibit apoptosis in response to UV damage. Oncogene 19: 592-598. 
Jonason, A.S., Kunala, S., Price, G.J., Restifo, R.J., Spinelli, H.M., Persing, J.A., Leffell, D.J., Tarone, R.E., and Brash, D.E. 1996. Frequent clones of p53-mutated keratinocytes in normal human skin. Proc Natl. Acad. Sci. 93: 14025-14029.

Lindner, G., Botchkarev, V., Botchkareva, N., Ling, G., van der Veen, C., and Paus, R. 1997. Analysis of apoptosis during hair follicle regression (catagen). Am. J. Pathol. 151: 16011607.

McCall, C. and Cohen, J. 1991. Programmed cell death in terminally differentiating keratinocytes, role of endogenous endonuclease. J. Inv. Dermatol. 97: 111-114.

Miralles, F., Parra, M., Caelles, C., Nagamine, Y., Felez, J., and Munoz-Canoves, P. 1998. UV irradiation induces the murine urokinase-type plasminogen activator gene via the c-jun $\mathrm{N}$ terminal kinase signaling pathway, requirement of an AP1 enhancer element. Mol. Cell. Biol. 18: 4537-4547.

Missero, C., Di Cunto, F., Kiykawa, H., Koff, A., and Dotto, G. 1996. The absence of p21Cip1/Waf1 alters keratinocyte growth and differentiation and promotes ras-tumor progression. Genes \& Dev. 10: 3065-3075.

Mitra, R. S., Wrone-Smith, T., Simonian, P., Foreman, K.E., Nunez, G., and Nickoloff, B.J. 1997. Apoptosis in keratinocytes is not dependent on induction of differentiation. Lab. Invest. 76: 99-107.

Partik, G., Kahl-Rainer, P., Sedivy, R., Ellinger, A., Bursch, W., and Marian, B. 1998. Apoptosis in human colorectal tumours, ultrastructure and qualitative studies on tissue localisation and association with Bak expression. Virchows Arch. 432: 415-426.

Polakowska, R., Piacentini, M., Bartlett, R., Goldsmith, L., and Haake, A. 1994. Apoptosis in human skin development, morphogenesis, periderm and stem cells. Dev. Dyn. 199: 176-188.

Ponten, F., Berne, B., Ren, Z.P., Nister, M., and Ponten J. 1995. Ultraviolet light induces expression of p53 and p21 in human skin: effect of sunscreen and constitutive p21 expression in skin appendages. Soc. Invest. Dermatol. 105: 402406.

Proby, C., Storey, A., McGregor, J., and Leigh, I. 1996. Does human papillomavirus infection play a role in non-melanoma skin cancer? Papillomavirus Rep. 7: 53-60.

Prunerias, M., Regnier, M., and Woodley, D. 1983. Methods of cultivation of keratinocytes at an air liquid interface. J. Invest. Derm. 81: 28-33.

Purdie, K.J., Pennington, J., Proby, C.M., Khalaf, S., de Villiers, E.-M., Leigh, I.M., and Storey, A. 1999. The promoter of a novel human papillomavirus (HPV 77) associated with skin cancer displays UV responsiveness, which is mediated through a consensus p53 binding sequence. EMBO J. 18: 5359-5369.

Rapp, B., Pawellek, A., Kraetzer, F., Schaefer, M., May, C., Purdie, K., Grassman, K., and Iftner, T. 1997. Cell-type-specific separate regulation of the E6 and E7 promoters of human papillomavirus type 6 a by the viral transcription factor E2. J. Virol. 71: 6956-6966.

Ren, Z.P., Hedrum, A., Ponten, F., Nister, M., Ahmadian, A., Lundeberg, J., Uhlen, M., and Ponten, J. 1996. Human epidermal cancer and accompanying precursors have identical p53 mutations different from p53 mutations in adjacent areas of clonally expanded non-neoplastic keratinocytes. Oncogene 12: 765-773.

Rodriguez, M.S., Desterro, J.M.P., Lain, S., Midgley, C.A., Lane, D.P., and Hay, R.T. 1999. SUMO-1 modification activates the transcriptional response of p53. EMBO J. 18 6455-6461.

Scheffner, M., Werness, B.A., Huibregtse, J.M., Levine, A.J., and Howley, P.M. 1990. The E6 oncoprotein encoded by HPV types 16 and 18 promotes the degradation of p53. Cell 63: $1129-1136$.

Schwarz, A., Bhardwaj, R., Argane, Y., Mahnke, K. Reimann, H., Metze, D., Lugar, T., and Schwarz, T. 1995. Ultraviolet Binduced apoptosis of keratinocytes: Evidence for partial involvement of tumour necrosis factor-alpha in the formation of sunburn cells. J. Invest. Dermatol. 104: 922-927.

Sieberg, M., Marthinuss, J., and Stenn, K. 1995. Changes in expression of apoptosis-associated genes in skin mark early catagen. J. Invest. Dermatol. 104: 78-82.

Storey, A., Thomas, M., Kalita, A., Harwood, C., Gardiol, D., Mantovani, F., Breuer, J., Leigh, I., Matlashewski, G., and Banks, L. 1998. Role of p53 polymorphism in the development of human papillomavirus-associated cancer. Nature 393: 229-234.

Thomas, M. and Banks, L. 1998. Inhibition of Bak-induced apoptosis by HPV-18 E6. Oncogene 17: 2943-2954.

Tomkova, H., Fujimoto, W., and Arata, J. 1997. Expression of Bcl-2 antagonist Bak in inflammatory and neoplastic skin diseases. Br. J. Dermatol. 137: 703-708.

Werness, B.A., Levine, A.J., and Howley, P.M. 1990. Association of human papillomavirus types 16 and 18 E6 proteins with p53. Science 248: 76-79.

Young, A. 1987. The sunburn cell. Photodermatol. 4: 127-134.

Ziegler, A., Jonason, A.S., Leffell, D.J., Simon, J.A., Sharma, H.W., Kimmelman, J., Remington, L., Jacks, T., and Brash, D.E. 1994. Sunburn and p53 in the onset of skin cancer. Nature 372: 773-776. 


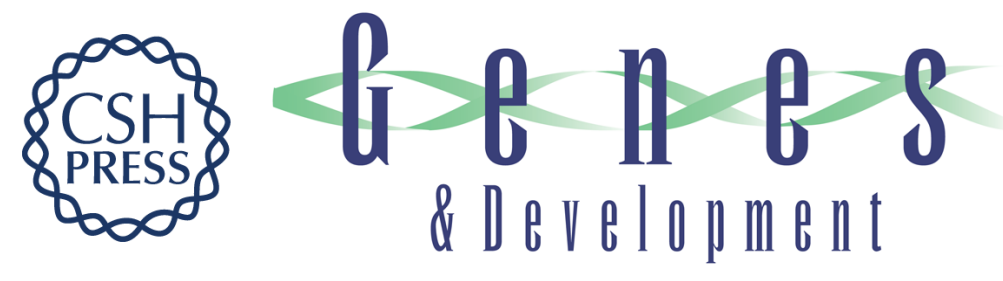

\section{Role of Bak in UV-induced apoptosis in skin cancer and abrogation by HPV E6 proteins}

Sarah Jackson, Catherine Harwood, Miranda Thomas, et al.

Genes Dev. 2000, 14:

Access the most recent version at doi:10.1101/gad.182100

References

This article cites 35 articles, 10 of which can be accessed free at: http://genesdev.cshlp.org/content/14/23/3065.full.html\#ref-list-1

\section{License}

Email Alerting

Receive free email alerts when new articles cite this article - sign up in the box at the top Service right corner of the article or click here.

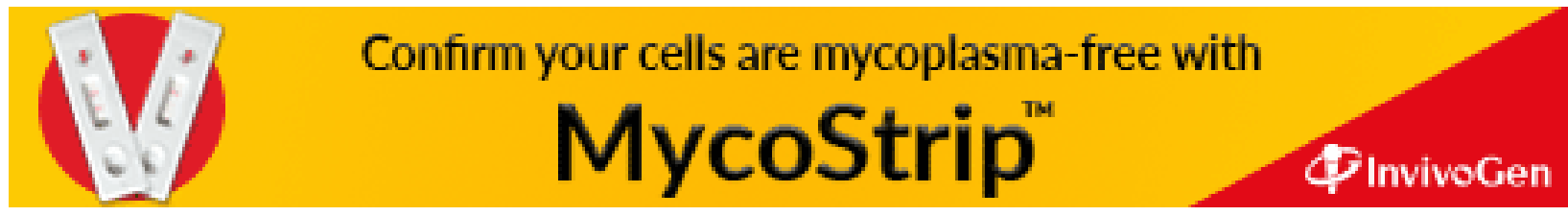

